\title{
Production and applications of xylanases - an overview
}

\author{
Girisha Malhotra, ShilPa S. ChapadgaOnKaR * \\ Manav Rachna International University, Department of Biotechnology, Faridabad, Haryana, India
}

\begin{abstract}
Endo-1, 4- $\beta$-xylanase is an enzyme that depolymerises xylan, a major component of lignocellulose. The economic utilization of lignocellulosic biomass as a feedstock for the production of fuel and chemicals would represent a paradigm shift in industrial carbon utilization, allowing sustainable resources to replace the non-renewable energy resources like petroleum. However, lignocellulose is a highly recalcitrant material that is extremely difficult to depolymerize. Many microorganisms possess repertoires of enzymes which act synergistically to decompose various components of lignocellulosic biomass into simple sugars. Biomass-utilizing organisms are widely distributed within different species of archaea, bacteria, fungi, protists, plants, and animals. These organisms possess numerous lignocellulolytic enzymes that can hydrolyze cellulose, hemicelluloses, or lignin. The present paper gives a detailed account of strategies for production, purification and application of microbial xylanases. Conversion of lignocellulose into fermentable sugars and subsequent conversion into bioethanol has been discussed in the present paper.
\end{abstract}

Key words: xylanase, lignocellulose, hemicellulose, fermentation, xylosidase, pulp bleaching

\section{Introduction}

The alarming levels of pollution and depletion of nonrenewable resources of energy have now compelled the world to look for alternative sustainable sources of energy. India's agriculture is mostly based on an economy that produces abundant amounts of lignocellulosic (agricultural and forestry) wastes, grasses, and woody materials every year. The dwindling reserves of nonrenewable resources of energy have driven the research to develop viable sustainable technologies. Lignocellulosic waste has been recognized as a sustainable source of fermentable sugars that can be fermented further to obtain value-added products (Fig. 1) such as animal feed, single-cell protein, ethanol, xylitol, furfural, organic acids, methane, and monosaccharides.

Despite numerous technologies being developed, low selectivity and high cost of the process remain a major bottleneck for the conversion of lignocellulosic biomass into value-added fine chemicals. Globally, extensive research is being carried out to address this hurdle.
Keeping pace with the world, Indian government has developed several initiatives to boost research in the field of biomass utilization for the production of biofuel and other value-added products and to facilitate the translation of technologies from research to actual commercial application. In recent times, India has faced unprecedented pollution due to the burning of agricultural waste. The economic feasibility and increase in social awareness remain major challenges for the implementation of technology that can convert agricultural waste into value-added products.

The main component of lignocellulose is cellulose, a $\beta(1 \rightarrow 4)$-linked chain of glucose molecules. Hydrogen bonds between different layers of polysaccharides contribute to the resistance of crystalline cellulose to degradation. Hemicellulose, the second most abundant component of lignocellulose, is composed of various 5- and 6-carbon sugars such as arabinose, galactose, glucose, mannose, and xylose. Lignin is composed of 3 major phenolic components, namely, p-coumaryl alcohol $(\mathrm{H})$, coni-

\footnotetext{
* Corresponding author: Manav Rachna International University, Department of Biotechnology, Faridabad, Haryana, India; e-mail: shilpas.fet@mriu.edu.in
} 


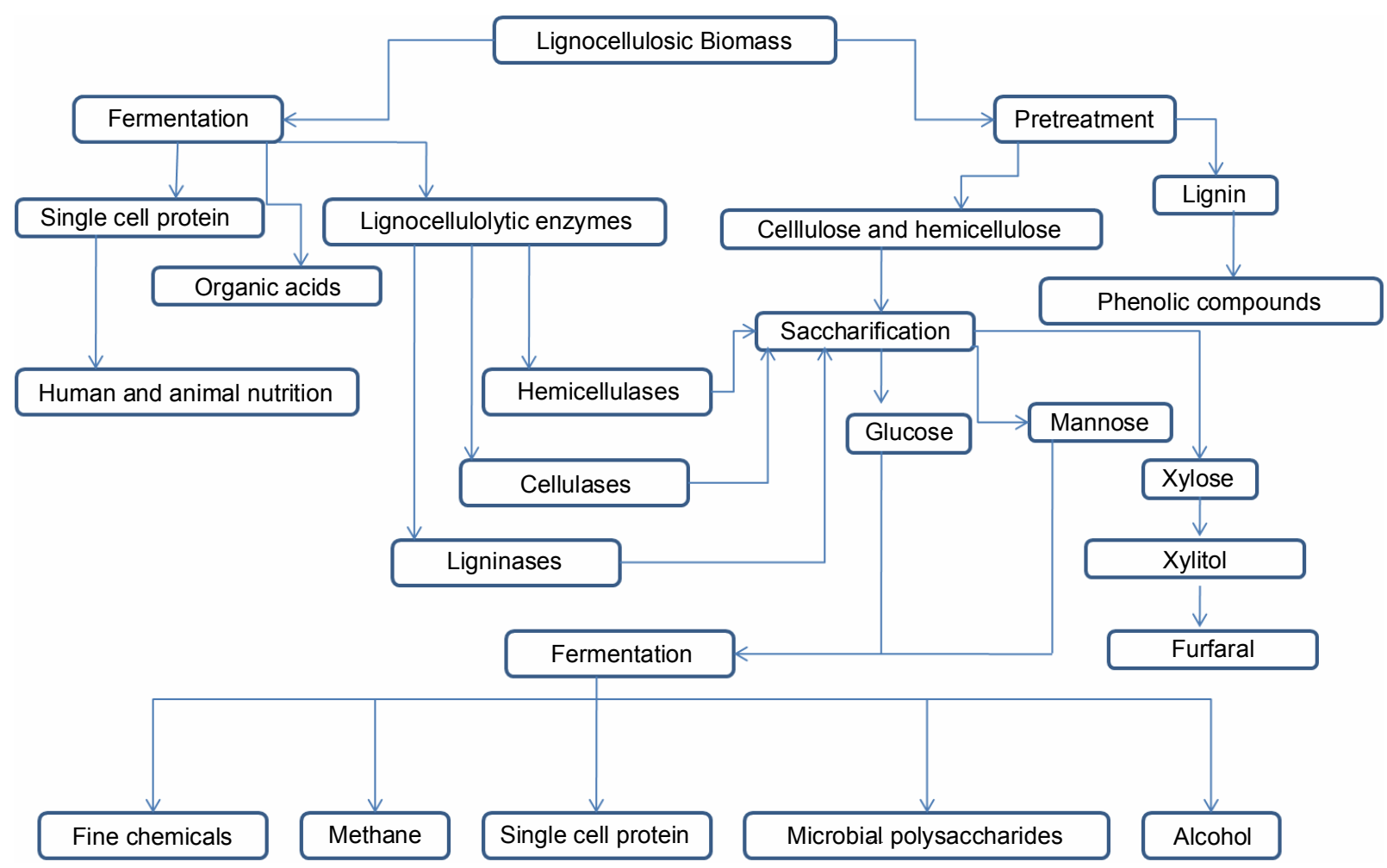

Fig. 1. Bioconversion of lignocellulosic biomass intop value added products

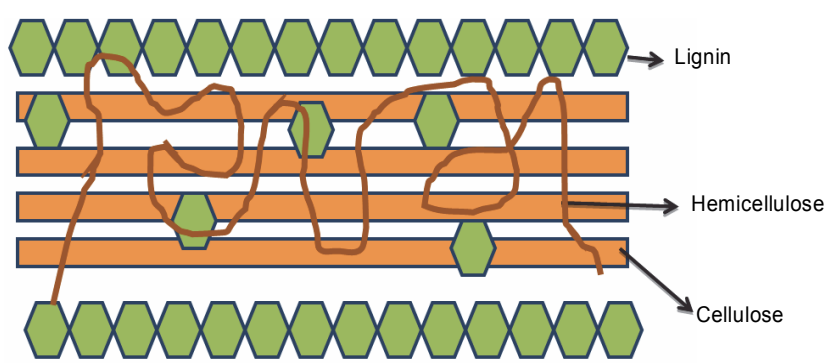

Fig. 2. Diagrammatic representation of lignocellulosic waste showing lignin, cellulose and hemicellulose fractions

feryl alcohol (G), and sinapyl alcohol (S) in varying proportions among different plant species and their parts (Fig. 2).

Xylan is a major component of hemicellulose and is a potential raw material for obtaining fermentable sugars that can be converted into several valuable products (Fig. 3). Because chemical methods of lignocellulose degradation are polluting and energy inefficient, enzymatic saccharification has gained importance.

Xylan has $\beta$-1,4-linked D-xylopyranose as a backbone and short chains of o-acetyl, $\alpha$-L-arabinofuranosyl, and $\alpha$ D-glucuronyl residues. Several xylanolytic enzymes act synergistically to hydrolyze xylan completely, for ex- ample, endo-1, 4- $\beta$-xylanase, $\beta$-D-xylosidase, $\alpha$-L-arabinofuranosidases, $\alpha$-glucoronidases, and acetyl esterases (Poutanen et al., 1987).

A large variety of microorganisms such as bacteria, yeasts, and fungi are efficient producers of xylanases (Subramaniyan and Prema, 2000). Xylanases are commercially important because of their ability to catalyze the bioconversion of lignocellulosic material and agrowastes into high-value products such as furfural, xylitol, biofuels, and artificial low-calorie sweeteners (Polizeli et al., 2005; Parajò et al., 1998). Xylanolytic enzymes are known to improve the digestibility of animal feed, because they break down arabinoxylans and reduce the viscosity of the raw material (Twomey et al., 2003). Nowadays, the pretreatment of pulps prior to bleaching in the pulp and paper industry is the most important industrial application of xylanases (Salles et al., 2005). As compared with that in the conventional paper pulping process, the modern methods involving enzymatic paper pulping and bleaching are responsible for the considerable decline in the release of toxic chlorine compounds into the environment. It also enhances the extraction of lignin from the pulp (Gupta et al., 2000). Xylanases, like any other hemicellulases, break down the hemicelluloses in 


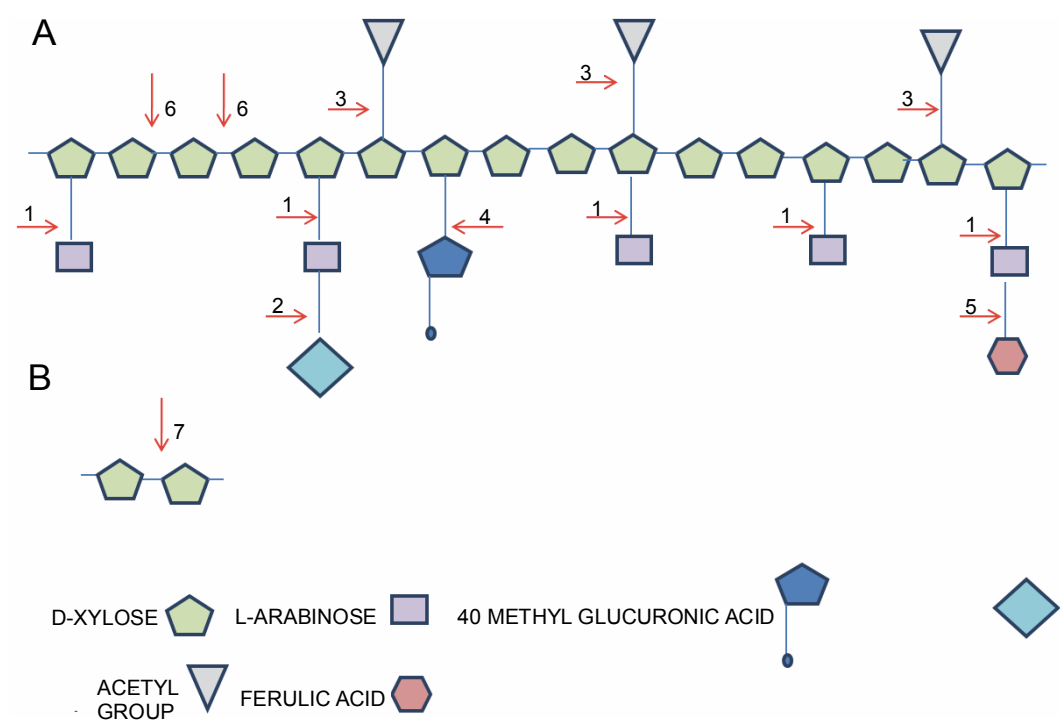

Fig. 3. A) Structure of xylan and the sites of its attack by xylanolytic enzymes; the backbone of the substrate is composed of $1,4-\beta$-linked xylose residues; B) complete degradation involves action of $\beta$-D-xylosidase on xylo-oligosaccharide; the enzymes that catalyze the specific reactions are given as numbered arrows (1) $\alpha$-L-arabinofuranosidases, (2) $\alpha$-D-galactosidase, (3) acetyl-xylan esterase, (4) $\alpha$-D-glucuronidase, (5) feruloyl esterase, (6) endo 1,4- $\beta$-xylanase (B) complete hydrolysis (7) $\beta$-D-xylosidase

Table 1. Process conditions for the production of xylanase from different microbial sources

\begin{tabular}{|c|c|c|c|c|}
\hline Microorganism & Media & $\begin{array}{l}\text { Culture } \\
\text { conditions }\end{array}$ & Activity & References \\
\hline \multicolumn{5}{|c|}{ Fungi } \\
\hline Penicillium canescens & soya oil cake and casein peptone & $\mathrm{pH} 7 ; 30^{\circ} \mathrm{C}$ & $18895 \mathrm{IU} / \mathrm{g}$ & $\begin{array}{l}\text { Assamoi et al., } \\
2010\end{array}$ \\
\hline Thermomyces lanuginosus SD-21 & $\begin{array}{l}\text { wheat bran, Corn cob } \\
\& \mathrm{NH}_{3}\left(\mathrm{SO}_{4}+\right)_{3}\end{array}$ & $\mathrm{pH} 6 ; 40^{\circ} \mathrm{C}$ & $8,237 \mathrm{IU} / \mathrm{ml}$ & $\begin{array}{l}\text { Ge et al., } \\
2011\end{array}$ \\
\hline Acremonium furcatum & $\begin{array}{l}\text { oat spelt xylan, urea, peptone } \\
\text { \& yeast extract }\end{array}$ & $\mathrm{pH} 7 ; 30^{\circ} \mathrm{C}$ & $33.1 \mathrm{IU} / \mathrm{ml}$ & $\begin{array}{l}\text { Palaniswamy et al., } \\
2008\end{array}$ \\
\hline \multirow{2}{*}{$\begin{array}{l}\text { Aspergillus niger PPI } \\
\text { Aspergillus niger }\end{array}$} & oat \& urea & $\mathrm{pH} 5 ; 28^{\circ} \mathrm{C}$ & $16.01 \mathrm{IU} / \mathrm{g}$ & $\begin{array}{l}\text { Pandey and Pandey; } \\
2002\end{array}$ \\
\hline & wheat bran & $\mathrm{pH} 5.5 ; 35^{\circ} \mathrm{C}$ & $35.5 \mathrm{IU} / \mathrm{ml}$ & $\begin{array}{l}\text { Gawande and Kamat; } \\
1999\end{array}$ \\
\hline Aspergillus terreus & wheat bran & $\mathrm{pH} 5.5,35^{\circ} \mathrm{C}$ & $38.5 \mathrm{IU} / \mathrm{ml}$ & $\begin{array}{l}\text { Gawande and Kamat; } \\
1999\end{array}$ \\
\hline \multicolumn{5}{|c|}{ Bacteria } \\
\hline Neocallimastix sp. Strain L2 & avicel (PH 105) from serva & $\mathrm{pH} 7 ; 50^{\circ} \mathrm{C}$ & $1.13 \mathrm{IU} / \mathrm{g}$ & $\begin{array}{l}\text { Dijkerman et al.; } \\
1997\end{array}$ \\
\hline Bacillus circulans D1 & bagasse hydrolysates & $\mathrm{pH} 9 ; 45^{\circ} \mathrm{C}$ & $8.4 \mathrm{IU} / \mathrm{ml}$ & $\begin{array}{l}\text { Bocchini et al.; } \\
2005\end{array}$ \\
\hline Paecilomyces thermophila J18 & wheat bran and yeast extract & $\mathrm{pH} 6.9 ; 50^{\circ} \mathrm{C}$ & $18580 \mathrm{IU} / \mathrm{g}$ & $\begin{array}{l}\text { Yang et al.; } \\
2006\end{array}$ \\
\hline Arthrobacter sp. MTCC5214 & wheat bran & $\mathrm{pH} 9 ; 50^{\circ} \mathrm{C}$ & $35.70 \mathrm{IU} / \mathrm{ml}$ & $\begin{array}{l}\text { Khandeparker } \\
\text { and Bhosle; } 2006\end{array}$ \\
\hline
\end{tabular}


wheat flour, helping in the redistribution of water and leaving the dough softer and easier to knead (Butt et al., 2008). Both current and potential applications of xylanases have been discussed in detail in this paper.

Xylanases produced by microorganisms are favored over xylanases produced from plants and animals because they are easily available, structurally stabler, and genetically easily manipulatable (Bilgrami and Pandey, 1992). Several agricultural waste materials such as wheat bran, rice straw, waste food material and cow dung have been used as carbon sources by many researchers for xylanase production. This paper dwells on potential applications of xylanases and development of suitable nutrient media supporting microbial growth for xylanase production.

\section{Classification of xylanases}

The complexity and variety of the structure and composition of xylans have led to the evolution of hundreds of xylanases. In an earlier system of classification given by Wang et al., in 1988, xylanaseswere classified into two groups based on their physicochemical properties: one group comprised of low molecular weight proteins $(<30 \mathrm{kDa})$ with basic pI, whereas the other group was composed of high molecular weight proteins $(>30 \mathrm{kDa})$ with acidic pI. This system of classification was inadequate to classify many known xylanases; therefore, a more complete classification for different types of glycosidases including xylanases was established (Collins et al., 2005). This classification is based on the primary structure of catalytic domains and the enzymes sharing sequence similarities have been grouped together. Principally, xylanases have been classified in Glycoside hydrolase families 10 (GH10) and 11 (GH11). However, the xylanolytic activities have also been found in other classes, of which some are bifunctional enzymes. The catalytic mechanism of xylanases, belonging to classes 10 and 11, involves hydrolysis of xylans with the retention of the anomeric center of the reducing sugar monomer of the carbohydrate. The reaction is known to be a double-displacement reaction, wherein a covalent glycosyl enzyme is formed as an intermediate and is hydrolyzed via oxocarbenium ion-like transition state. Two glutamic acid residues, which are appropriately located at the active site, are involved in the formation of a transition state. One acts as a general acid catalyst by protonating the substrate, whereas the other attacks nucleo- philically, which results in a release of a leaving group to form the $\alpha$-glycosyl enzyme intermediate ( $\beta$ to $\alpha$ conversion). In the second step, the first carboxylate group functions as a general base to extract a proton from a water molecule that attacks the anomeric carbon. This leads to a cleavage of a glycosidic bond and an inversion of the configuration of the anomeric carbon that is, $\alpha$ to $\beta$ conversion (Biely et al., 2003).

Glycoside hydrolase family 10 comprises endo-1,4- $\beta$ xylanases and endo-1,3- $\beta$-xylanases. Members of this family can also hydrolyze the aryl $\beta$-glucosides of xylobiose and xylotriose at the aglyconic bond. Structural analyses on xylooligosaccharides of various sizes and end product analyses have indicated that family 10 xylanases typically have $4-5$ substrate-binding sites. Members of this family also typically have a high molecular mass, a low pI, and display an $(\alpha / \beta)$-barrel fold (Teplitsky et al., 2000). Distinct roles have been described for carbohydrate-binding modules GH10 and GH11 xylanases from Caldicellulosiruptorsp. strain F32 in thermostability and catalytic efficiency (Meng et al., 2015).

Glycoside hydrolase Family 11 is composed of xylanases that typically only have a high pI and a low molecular weight. The catalytic mechanism is similar to that of GH10 xylanases. They possess $\beta$-jelly roll fold structure. GH11 xylanases exhibit high substrate selectivity and a high catalytic efficiency. The products of GH11 xylanase reactions can be further degraded by family 10 enzymes. Similar to family 10 xylanases, these enzymes can hydrolyze the aryl $\beta$-glycosides of xylobiose and xylotriose at the aglyconic bond, but they are inactive on aryl cellobiosides. However, these enzymes carry out most of their activity on long-chain xylooligosaccharides, which is enabled by their bigger substrate-binding clefts (Collins et al., 2005).

GH10 xylanases are catalytically more versatile and have low substrate specificity as compared with that of GH11 xylanases. Xylanases from family 11 preferentially cleave the unsubstituted regions of the arabinoxylans backbone, whereas GH10 enzymes cleave the regions with greater substitution (Collins et al., 2005).

\section{Sources of microbial xylanases}

Xylanase production by many species of bacteria as well as fungi has been reported. The filamentous fungi have a remarkable ability to thrive on various recalcitrant substrates. These species possess a diverse reper- 
toire of enzymes required for the hydrolysis and utilization of complex organic substrates, and therefore can utilize complex carbohydrates present in lignocellulosic waste materials such as dead leaves, stored grains, compost piles, and other decaying materials (Chen et al., 1999; Wu et al., 2000; Haq et al., 2002).The prominent fungal species among those are strains of Penicillium sp. (Fadel and Fouda, 1993; Gasper et al., 1997), Trichoderma sp. (Liu et al., 1999), and Aspergillus sp. (Pinaga et al., 1994; Ganga et al., 1998; Ito et al., 2000). Industrially, $A$. niger and $T$. reesei are two most important filamentous fungi that are used for the production of xylanases.

Fungi have been reported to produce xylanases with a higher activity and concentration as compared with that produced by bacteria. However, they also secrete cellulases, a feature highly undesirable for some industrial applications, especially paper pulping and bleaching processes (Walia et al., 2017). This is because the degradation of cellulose increases the viscosity of the process mixture. Moreover, industrial application of fungal and actinomycetes species is also hampered by their slow generation times, difficult oxygen transfer, and a production of viscous by-products during fermentation (Boucherba et al., 2017). Bacterial xylanases are free from cellulase activity and are reported to possess higher temperatures and $\mathrm{pH}$ optima, which are desirable for industrial applications (Okazaki et al., 1985; Khasin et al., 1993). Among bacteria, the genus Bacillus has been studied extensively due to its rapid growth and for its capacity to secrete important extracellular enzymes and proteins into the medium. Other bacterial species reported for the production of xylanases are Streptomyces, Cellulomonas, Micrococcus, Staphylococcus, Thermotoga, Paenibacillus, Arthrobacter, Microbacterium (Patel et al., 1994; Kansoh and Gammel, 2001; Hiremath and Patil, 2011; Roy and Habib, 2009; Rawashdeh et al., 2005). Figure 1 lists some of the important microbial sources of xylanases and the optimal process conditions for xylanase production.

\section{Molecular regulation of xylanase production in microorganisms}

The xylanase genes are organized as clusters and consist of different genes with functionally different gene products (Baba, 1994; Gosalves et al., 1991; MacKenzie et al.,
1989). The xylanolytic enzyme cluster of $B$. subtilis strain 168 consists of four different genes: $x y n A$ that encodes endo-1,4 $\beta$-xylanase, $x y n B \beta$-xylosidase, whereas $x y n C$ encodes GH30 family endoxylanase (Chakdar et al., 2016).

Xylans cannot penetrate the cell wall barrier; therefore, they cannot induce the production of xylanases. A small amount of xylanase is expressed constitutively, which results in a degradation of a small amount of xylans into xylose, xylobiose, and lignocellulosic residues that contain xylose. Xylose can penetrate the cell easily to induce xylanase activity (Motta et al., 2013), where they act as potent inducers of xylanase production. However, the role of higher molecular weight molecules obtained from xylan degradation is debatable because of their difficulty in crossing the cell wall. The higher molecular weight xylan fragments are either hydrolyzed during the transportation or xylooligomers are directly transported to the cytoplasm, where they are hydrolyzed by intracellular $\beta$-xylosidases (Gomes et al., 1994). The extent of induction is also dependent on the nature and concentration of the carbon source in the nutrient medium (Lemos and Peirera Junior, 2002).

Xylanase production is subjected to carbon catabolite repression, that is, the easily metabolizable carbon source represses the expression of the enzyme (Piñaga et al., 1994; Flores et al., 1996; Kadowaki et al., 1997; Archana and Satyanarayana, 1997; Kermnický and Biely, 1998). Rarely, xylose molecules have been reported to repress xylanase production. Xylanase inducers require transferases for intracellular transportation (Kulkarni et al., 1999). The presence of glucose or other easily metabolizable sugars can block the transport of inducer molecules resulting in the inhibition of xylanase production. This inhibitory mechanism is known as inducer exclusion (Peij et al., 1998). The accumulation of end products of xylan hydrolysis has been reported to inhibit some of the xylanases activity (Royer and Nakas, 1991).

\section{Production and purification of xylanases}

Xylanases have been produced using solid-state as well as submerged culture processes. The submerged culture processes have already been well-established in the bioprocess industry as it is more amenable to control and scale-up (Rodriguez et al., 2014). Several processes have been optimized for the production of xylanases using submerged fermentation. Optimization of process 
parameters such as growth and production medium, $\mathrm{pH}$, agitation, aeration, and cultivation time can result in a remarkable enhancement in the xylanase production yield. Several researchers have used statistical optimization techniques with higher xylanase production as the objective (Ghoshal et al., 2015a; Gupta et al., 2013; Rodriguez et al., 2014; Thomas et al., 2013). Solid-state fermentation is also popular because of high yield, simplicity of the process, and low risk of contamination (Agnihotri et al., 2010).

Several different types of bioreactors have been studied for xylanase production such as a stirred-tank bioreactor, an air-lift bioreactor, and bubble column reactors (Wase et al., 1985). The stirred-tank reactor has been extensively explored for the production of xylanases (Kim et al., 1997). Ghoshal and coworkers (2015) optimized the process parameters such as $\mathrm{pH}$, agitation, and aeration for xylanase production by Penicillum citrinum MTCC 9620 in a stirred-tank bioreactor, resulting in 2.5 times increase in enzyme activity as compared with that in shake flask studies. Gupta and coworkers (2013) reported xylanase production from Melanocarpus albomyces using wheat straw as a substrate and its scale-up in a stirred-tank bioreactor. Maximum enzyme activity of about $520 \mathrm{IU} / \mathrm{ml}$ in $36 \mathrm{~h}$ of fermentation was reported. Michelin and coworkers (2013) observed the production of xylanase by $A$. niger in a stirred-tank and internal loop air-lift bioreactors. Bakri and coworkers (2011) compared xylanase production in a batch and continuous mode in a stirred-tank bioreactor using $P$. canescens. The authors observed that maximum xylanase productivity was $1.31 \mathrm{U} / \mathrm{ml} / \mathrm{h}$, after $96 \mathrm{~h}$ of batch cultivation, whereas continuous cultivation resulted in the production of $3.46 \mathrm{U} / \mathrm{ml} / \mathrm{h}$ of xylanase.

\section{Solid-state fermentation}

Several researchers have renewed interest in solidstate fermentation, especially for lignocellulose degrading enzymes because of economical and practical advantages such as simplicity, low capital costs for equipment and operations, lesser space requirements, and easier downstream processing (Holker et al., 2004; Mitchell et al., 2002; Pandey et al., 2000). Studies involving the production of fungal xylanases in solid-state fermentation have shown to obtain very high yields of xylanases as compared with that in the submerged fermentation method. This could be as a result of a poor oxygen supply and shear disruption of fragile fungal biomass in the stirred-tank reactor used for submerged fermentation (Roy et al., 2013; Jain et al., 2013; Gasper et al., 1997).

For the production of xylanases, the conventional tray-type reactor has been most commonly used by various researchers (Ali et al., 2000; Alberton et al., 2009; Kim et al., 1997). However, it suffers from serious limitation of aeration for the active aerobic culture. Other reactor configurations such as packed-bed reactors have also been used for xylanase production (Bück et al., 2015). The main process parameters affecting the production are aeration, temperature, $\mathrm{pH}$, and water content. The main drawback for solid-state fermentation in packed-bed bioreactors is the development of gradients of temperature and moisture along the reactor length, which decrease the overall productivity level (Bück et al., 2015).

Ghoshal and coworkers (2015) used agricultural residues supported on sugarcane bagasse as a carbon source for xylanase production in solid-state fermentation. They optimized process conditions such as $\mathrm{pH}$ (5.0), moisture content $\left(1: 5\right.$ at $\left.30^{\circ} \mathrm{C}\right)$, and time of incubation (5 days). Umsza-Guez et al. (2011) constructed a plate-type bioreactor for solid-state fermentation of tomato pomace for the production of xylanase. The reactor had forced circulation of humidified air. Enzyme production could be enhanced several times by better aeration. The enzyme was activated by magnesium ions. Deshpande and coworkers (2008) studied the production of cellulase and xylanase in a solid-state cabinet fermenter. They utilized a solid medium containing the weed water hyacinth, and reported that cellulase production by $T$. reesei was higher in a solid-state cabinet fermenter as compared with that in a submerged culture. The supplementation of Toyoma Ogowa (TO) medium with whey $(40 \%)$ and peptone $(0.15 \%)$ further enhanced the production of both cellulase complex and xylanase by 2-3 folds. Rodriguez (2014) established mixed cultures of four different strains of $A$. niger and Rhizopus stolonifer in a laboratory-scale horizontal tube bioreactor using corncob as a solid substrate. The highest xylanase activity $(2,926 \mathrm{U} / \mathrm{g} \mathrm{dcc})$ at an air flow rate of $0.2 \mathrm{l} / \mathrm{min}$ was observed. The results showed an overall 5.8 -fold increase in xylanase activity after the optimization of the culture medium, operational conditions, and scale-up. However, solidstate fermentation still suffers limitations such as low ca- 
pacity and a lower process control, and therefore research on novel bioreactor configurations would greatly benefit a better application of this technique.

\section{Purification of xylanases}

Xylanases have been purified from several sources including bacteria, fungi, insects, and so on. Most of the researchers have relied on conventional purification by multistep procedures involving primary separation using filtration or centrifugation followed by precipitation, ultrafiltration, and sequential chromatographic steps (Irfan and Sayed, 2012; Taneja et al., 2002; Kamble and Jadhav, 2012; Silva et al., 1999). Several researchers have reported the occurrence of multiple xylanase enzymes in xylanases purified from several microbial sources. In a recent report, Liao and coworkers (2015) have isolated and identified eight different xylanases from P. oxalicum GZ-2 using agricultural wastes as a substrate. Multiple enzymes equip the microorganisms in the ability to hydrolyze heterogeneous lignocellulosic biomasses found in nature.

Silva et al. (2015) purified two xylanases, Xyl I and Xyl II, from the crude extracellular extract of a $T$. inhamatum strain cultivated in a liquid medium with oat spelts xylan. They utilized ion exchange chromatography using diethylaminoethanol (DEAE)-Sepharose and subsequent gel filtration chromatography using Sephadex G-75 to obtain Xyl I and Xyl II in a pure form as estimated by SDS-PAGE. The molecular weights were determined as $19 \mathrm{kDa}$ for $\mathrm{Xyl} I$ and $21 \mathrm{kDa}$ for Xyl II. Kamble and Jadhav (2012) purified xylanase from a new species of Bacillus (similar to B. arsenicoselenatis DSM 15340), by first precipitating using ammonium sulfate (80\%), followed by purifying using ion exchange chromatography. The molecular weight of xylanase was determined to be $29.8 \mathrm{kDa}$. Silva and coworkers (1999) purified two types of xylanases from $A$. fumigates Fresenius, by a combination of ultrafiltration and chromatographic procedures. The ultrafiltrate was subjected to gel filtration chromatography on Sephadex G-50 and two separate peaks of xylanase activity (I and II) were obtained. The second peak, designated as xylanase II, was used for further purification by hydroxyl apatite and anion-exchange chromatography.

Ratanakhanokchai and coworkers (1999) purified xylanase from alkalophillic Bacillus $\mathrm{K} 1$ strain using affinity adsorption of xylanase on insoluble xylan. The cul- ture supernatant was incubated with insoluble xylan at $4^{\circ} \mathrm{C}$ in Tris buffer ( $\mathrm{pH} \mathrm{9.0)}$ and agitated periodically. The xylan-bound protein complex was eluted with $1 \%$ triethylamine. Lactosyl-Sepharose was prepared and tested as an affinity matrix for xylanase SoXyn 10A obtained from Streptomyces olivaceoviridis E-86 that comprised of a carbohydrate-binding module (SoCBM 13). Ito and coworkers (2004) used this property to design an affinity matrix lactosyl-Sepharose for purification of xylanases.

Silva and coworkers (2014) used extractive fermentation for xylanase production from $A$. tamarii. Fermentation was conducted in an aqueous two-phase system consisting of polyethylene glycol, sodium citrate, citric acid, yeast extract $(0.5 \%)$, cassava bark $(2 \%)$, and water. They obtained xylanase activity as high as $331.4 \mathrm{U} \mathrm{ml}^{-1}$. We have also reported an aqueous two-phase extraction system as an efficient method for primary isolation of xylanases (Malhotra et al., 2016). Extractive fermentation greatly improves the economy of the process by increasing the yield and reducing the number of processing steps. Klingspohn and Schügerl (1993) used acid supplemented with treated potato pulp and potato pulp residue for the production of cellulases and hemicellulases by $T$. reesei Rut C30 in a continuously operated bioreactor. The enzyme solution was recovered and concentrated continuously in line with the reactor. The integrated process resulted in very high productivities and enzyme titers.

\section{Genetic engineering of microorganisms for maximization of xylanase production}

Traditionally, strain improvement by radiation or chemical mutagenesis has been used to enhance xylanase yield obtained from the culture (Abdel-Aziz et al., 2011). In recent times, recombinant DNA technology has gained significance for the generation of strains for overexpression of production and complete lignocellulose hydrolysis (Thomas et al., 2013). Numerous patents have been granted globally for the processes that involved genetic engineering of microbial strains for xylanase production (Cheng et al., 2006; Dauvrin and Jonniaux, 2004). Several researchers have used $E$. coli as the expression host system for heterologous xylanase expression (Zafar et al., 2016; Elgharbi et al., 2015; Jun et al., 2009; Panbangred et al., 1985). The E. coliexpressed xylanases are functionally active, though they lack $\mathrm{N}$ glycosylation. However, they have lower specific activity 
and stability (Chang et al., 2017). Alternatively, Gram positive bacteria such as Lactobacillus species and B. subtilis have been used for xylanase expression (Liu et al., 2005; Verma and Satyanarayana, 2013). These species are capable of $\mathrm{N}$-glycosylation and higher protein production levels as compared with E. coli. Moreover, the Generally Recognized as Safe (GRAS) status of Lactobacillus makes it an attractive option for the heterologous protein expression.

Yeasts are also good hosts for expressing xylanases, as they are able to grow to very high cell densities and secrete proteins into the fermentation media. Maldonado and coworkers (2013) confirmed that a majority of glycosylated enzymes expressed in Pichia pastoris had a higher thermostability in comparison with that of their unglycosylated counterparts. The presence of a polyhistidine tag increased the thermostability of XYN10A xylanase, whereas glycosylation at Asn26, located in an exposed loop, decreased its thermostability (Anbarasan et al., 2010). Kluyvermyces lactis is yet another yeast species that can be a suitable host because of the ease in genetic manipulation and commercial availability (Walsh et al., 1998). Perez-Gonzalez and coworkers (1996) have expressed A. nidulans xylanase genes in Saccharomyces cerevisiae to understand the transcriptional regulation of xylanase and have found that xylanase production was induced at the transcriptional level by xylan and d-xylose and was repressed by D-glucose.

Filamentous fungi are preferred expression systems because of the ease in handling fungal cultivation and strain improvement they have already undergone (Nevalainenm et al., 2005). Xylanases have been expressed in T. reesei, A. kawachii, and A. niger (Xiong et al., 2016; Qiu et al., 2016; Takahashi et al., 2013). P. pastoris has been explored for the expression of transgenic xylanase. Xylanase expression in Pichia is affected by metal ions and other additives. $\mathrm{Hg}^{+2}, \mathrm{Fe}^{+2}, \mathrm{Co}^{+2}, \mathrm{Mn}^{+2}, \mathrm{Ag}^{+2}, \mathrm{Cu}^{+2}$, and $\mathrm{Pb}^{+2}$ ions and reagents such as urea and EDTA act as xylanase inhibitors, whereas $\mathrm{Ca}^{+2}$ and $\mathrm{Mg}^{+2}$ are the activators of the enzymes (Yinan et al., 2008; Zhou et al., 2009).

Transgenic plants that illustrate higher levels of xylanase expression, higher xylanase stability and simpler purification protocols as compared to native xylanase have been created. Bae et al., 2008 successfully produced recombinant xylanase in Arabidopsis and found that the highest accumulation of the protein occurred during flowering. Rice and tobacco plants have been genetically modified to express xylanases from Clostridium thermocellum (Kimura et al., 2003).

\section{Assay of xylanase}

Usually, xylanase activity is determined by measuring the increase in the amount of reducing groups during the enzymatic hydrolysis of xylan by the dinitrosalicylic acid method described by Bernfeld (Bernfeld P., 1955) or Miller (Miller, 1959), with xylose used as a standard. However, Miller method is more favored by the researchers. Remazol brilliant blue R-D-Xylan or Azoxylan may also be used as substrates (Juturu and $\mathrm{Wu}$, 2012 ), and in such cases $\beta$-xylosidase activity is measured as the release of p-nitrophenol from substrates (Ahmed et al., 2009; Biely et al., 1988). The amount of reducing sugars is determined by measuring the absorbance at $540 \mathrm{~nm}$. Birchwood xylan is the preferred substrate because of its low turbidity and a greater range of linearity (Bailey et al., 1992).

\section{Immobilization of enzyme}

Xylanases have been immobilized on different matrices following varied immobilization methods such as entrapment using gelatin, physical adsorption on chitin, ionic binding with Sepharose, and covalent binding with HP-20 beads. Immobilization imparts several benefits such as an increase in stability and reusability, which in turn can reduce the processing costs considerably. Dumitriu and coworkers (1997) reported successful covalent immobilization of endo-xylanase produced by $T$. viride on activated calcium alginate carrier. It was active at $98^{\circ} \mathrm{C}$, when hydrogels comprising polyanion xylan and polycation chitosan were used as carriers. Pal and Khanum (2011) observed that activation energy for denaturation of covalently immobilized xylanases on activated calcium alginate was about $20 \%$ greater than that of free enzyme, indicating the decreased inactivation of the immobilized ones. According to this report, immobilization increased the resistance of xylanases to cold denaturation. Gaur and coworkers (2005) isolated xylanases from Scytalidium thermophilum and immobilized them on Eudragit L-100, a pH-sensitive copolymer of methacrylic acid and methyl methacrylate. The immobilized enzyme had wider temperature range and $\mathrm{pH}$ optima as compared with the free one. 


\section{Applications of xylanases}

\section{Paper and pulp industry}

The xylanases prebleaching technology is now being used commercially in paper mills (Bajpai, 1999). Enzyme-aided kraft pulp bleaching is mainly performed by endo- $\beta$-xylanases (Viikari et al., 1994). Xylanases hydrolyze the reprecipitated xylan on the fibers of paper pulp. The permeability of fibers increases with xylanase treatment, which allows easier removal of lignin from the fibres. The use of xylanases reduces the requirement for polluting chlorine bleaches (Kantelinen et al. 1993). Presently available commercial xylanase enzymes generally require $\mathrm{pH}$ between $6-8$ and temperatures below $80^{\circ} \mathrm{C}$ (Tundo et al., 2016). Accordingly, the temperature and $\mathrm{pH}$ of the pulp needs to be adjusted before the enzymatic treatment. This has created a need for xylanases with a higher $\mathrm{pH}$ tolerance and temperature stability to reduce the processing costs. Therefore, xylanases with a higher $\mathrm{pH}$ and temperature stability are being given more attention nowadays (Huang et al., 2015; Kamble and Jadhav, 2012). Moreover, genetic engineering of xylanases is being performed to modify enzymatic activities in harsh conditions, but their overexpression has been and still is being explored (Sriprang et al., 2006; Fenel et al., 2014).

\section{Lignocellulose degradation}

Another potential application of xylanases is the conversion of agricultural and other lignocellulose residues into value-added products as shown in Figure 1. This process requires delignification of lignocelluloses to liberate cellulose and hemicelluloses from their complex structure with lignin. It is followed by depolymerization of carbohydrate polymer to produce free sugars, and finally by fermentation of simple sugars to produce ethanol (Beg et al., 2001). In view of the global interest in developing sustainable technologies, many lignocellulose pretreatment methods such as acid and alkali treatments, or steam explosion have been established to make the cellulose accessible for hydrolysis. Xylan is known to shield cellulose against the hydrolytic action of cellulolytic enzymes. Xylanase treatment improves the accessibility of cellulose to hydrolysis by increasing fiber swelling and porosity (Hu et al., 2011). Simultaneous Saccharification and Fermentation (SSF), Simultaneous Saccharification and Co Fermentation (SSCF), and Con- solidated Bioprocessing $(\mathrm{CB})$ are novel integrated processes that aim at reducing the process costs for the production of bioethanol.SSF is a novel process that integrates enzymatic hydrolysis and microbial fermentation into one single step. Consequently, enhancement in reaction rates and yields is obtained (Eklund and Zacchi, 1995; Sun and Cheng, 2002). SSCF involves fermentation of hexoses (C6) and pentoses (C5) into ethanol by a single microorganism (Teixeira et al., 2000). CB involves the production of ethanol and lignocellulose-degrading enzymes by a single microbial community in a reactor. This is possible due to using mono- or co-cultures of microorganisms. CB decreases the capital cost requirements for bioreactor facilities and operational costs that are incurred on external enzymes (Chadha et al., 1995).

Xylanases together with pectinases are commonly used for degumming of bast fibers such as flax, hemp, jute, and ramie (Paridah et al., 2011). Fibers are separated by the process of retting, that is, removal of the binding material present in the plant cells with the use of microbial enzymes. Natural retting is a slow process and produces pollutants, but this can be replaced by the use of a combination of enzymes that are environment friendly and achieve a rapid liberation of fibers (Arami et al., 2007).

\section{Applications in baking industry}

Xylanase treatment converts water insoluble hemicelluloses into soluble forms, which decrease the firmness and increase the volume of the dough (Jiang et al., 2005; Laurikainen et al., 1998; Rouau, 1993). The use of xylanases in various production processes may reduce the use of chemical additives such as bromates (Kulkarni et al., 1999). In the industrial separation of wheat starch and gluten, arabinoxylan interferes with efficient gluten coagulation (Biely, 2003). Therefore, xylanases can be used to facilitate the separation of wheat starch and gluten.

\section{Fruit juice clarification}

Fruit juices extracted from various fruits are turbid and viscous due to the presence of polysaccharides such as starch, pectins, cellulose, hemicelluloses, and bound lignins (Lee et al., 2006). Therefore, several enzymes such as pectinases, cellulases, and xylanases are being used to improve the organoleptic characteristics of the fruit juices (Kumar et al., 2014). 


\section{Animal feed industry}

Several patents, as well as research papers, describe the application of xylanases as feed additives that improve the nutritive value of animal feed and result in weight gain of the animals. Xylanases solubilize and degrade the insoluble polysaccharides (also known as nonstarch polysaccharides or NSP) (Fisher and Petersson, 2008, Bauer et al., 2008; Goswami and Pathak, 2013).

\section{Future scope}

In the future, consorted efforts of the microbiologists, synthetic biologists, and process scientists will play an important role in developing xylanases and other enzyme cocktails with very high specific activities as well as increased stability. Applications such as lignocellulose biomass degradation entail the development of a universal multifunctional enzyme that could deliver the technology for production of "green fuel" as well as many other products from the laboratory to the practice. Studies on upstream and downstream processes development are required to reduce the processing costs.

\section{References}

Abdel-Aziz M.S., Talkhan F.N., Fadel M., Abou Zied A.A., Abdel-Razik AS. (2011) Improvement of xylanase production from Streptomyces pseudogriseolus via UV mutagenesis. Aust. J. Basic Appl. Sci. 5: 1045-1050.

Agnihotri S., Dutt D., Tyagi C.H., Kumar A., Upadhyaya J.S. (2010) Production and physiochemical characterization of a novel cellulase-poor alkali-thermo-tolerant xylanase from Coprinellus disseminates SW-1 NTCC 1165. World J. Microbiol. Biotechnol. 26: 1349-1359.

Ahmed S., Riaz S., Jamil A. (2009) Molecular cloning of fungal xylanases: an overview. Appl. Microbiol. Biotechnol. 84: 19-35.

Ali H.Q., Zulkali M.M.D. (2011) Design aspects of bioreactors for solid state fermentation: a review. Chem. Biochem. Eng. Q. 25: 255-266.

Alberton L.R., Vandenberghe L.P., Assmann R., Fendrich R.C., Rodriguez-Leon J., Soccol C.R. (2009) Xylanase production by Streptomyces viridosporus T7A in submerged and solid-state fermentation using agro-industrial residues. Braz. Arch. Biol. Technol. 52: 171-180.

Anbarasan S., Janis J., Paloheimo M., Laitaoja M., Vuolanto M., Karimaki, J., Vainiotalo P., Leisola M., Turunen, O. (2010) Effect of glycosylation and additional domains on the thermostability of a family 10 xylanase produced by Thermopolyspora flexuosa. Appl. Environ. Microbiol. 76: 356-360.

Arami M., Rahimi S., Mivehie L., Mazaheri F., Mahmoodi N.M. (2007) Degumming of persian silk with mixed proteolytic enzymes. J. Appl. Polym. Sci. 106: 267-275.
Archana A., Satyanarayana T. (1997) Xylanase production by thermophilic Bacillus lichenifomis A99 in solid-state fermentation. Enzyme Microbiol. Technol. 21: 12-17.

Baba T., Shinke R., Nanmori T. (1994) Identification and characterization of clustered genes for thermostable xylan-degrading enzymes, $\beta$-xylosidase and xylanase of Bacillus stearothermophillus. Appl. Environ. Microbiol. 60: 2252-2258.

Bae H.J., Kim H.J., Kim Y.S. (2008) Production of a recombinant xylanase in plants and its potential for pulp biobleaching applications. Biores. Technol. 99 (9): 3513-3519.

Bailey M.J., Biely P., Poutanen K. (1992) Interlaboratory testing of methods for assay of xylanase activity. J. Biotechnol. 23: 257-270.

Bajpai P. (1999) Application of enzymes in the pulp and paper industry. Biotechnol. 15: 147-157.

Bakri Y., Akeed Y., Thonart P. (2011) Comparison between continuous and batch processing to produce xylanase by Penicillium canescens 10-10c. Brazil. J. Chem. Eng. 29: 441-447.

Bauer M.S. (2008) Microbially expressed xylanases and their use as feed additives and other uses. Assignee Syngenta Participations AG Patent no. EP 1771554 A4.

Bernfeld P. (1955) Amylases: alpha and beta methods. Enzymol. 1: 149-158.

Beg Q.K., Kapoor M., Mahajan L., Hoondal G.S. (2001) Microbial xylanases and their industrial applications: a review. Appl. Microbiol. Biotechnol. 56: 326-338.

Biely P., Mislovičová D., Toman R. (1988) Remazol brilliant blue-xylan: A soluble chromogenic substrate for xylanases. Meth. Enzymol. 160: 536-541.

Biely P. (2003) Diversity of microbial endo -1, 4-xylanases. [in:] Applications of Enzymes to Lignocellulosics. Ed. Mansfield S.D., Saddler J.N. Amer. Chem. Soc., Washington: $361-380$.

Bilgrami K.S., Pandey A.K. (1992) Industry and fermentation in introduction to biotechnology. (ES. K. Jain) 149-165.

Boucherba N., Gagaoua M., Bouanane-Darenfed A., Bouiche C., Bouacem K., Kerbous M. Y. Benallaoua S. (2017) Biochemical properties of a new thermo- and solvent-stable xylanase recovered using three phase partitioning from the extract of Bacillus oceanisediminis strain SJ3. Bioresour. Bioproces. 4(1): 29.

Butt M.S., Tahir-Nadeem M., Ahmad Z., Sultan M.T. (2008) Xylanases and their applications in baking industry. Food Technol. Biotechnol. 46(1): 22-31.

Bück A., Casciatri F.P., Thomeo J.C., Tsotsas E. (2015) Model based control of enzyme yield in solid-state fermentation. Procedia. Engg. 102: 362-371.

Chadha B.S., Kanwar S.S., Garcha H.S. (1995) Simultaneous saccharification and fermentation of rice straw into ethanol. Acta. Microbiol. Immunol. Hung. 42: 71-75.

Chakdar H., Kumar M., Pandiyan K., Singh A., Nanjappan K., Kashyap P.L., Srivastava A.K. (2016) Bacterial xylanases: biology to biotechnology. Biotechnologia 6: 150 .

Chang X., Xu B., Bai Y., Luo H., Ma R., Shi P., Yao B. (2017) Role of $\mathrm{N}$-linked glycosylation in the enzymatic properties 
of a thermophilic GH 10 xylanase from Aspergillus fumigatus expressed in Pichia pastoris. PLoS ONE 12(2): e0171111. https://doi.org/10.1371/journal.pone.0171111

Chen H., Jiang Z., Gaigin L., Zizheng Y., Shuzheng Z. (1999) Screening of acidic xylanase producing strain and studies on its enzyme production condition. Weishengwu Xuebao 39: 350-354.

Cheng K.J., Chen Y.C., Cheng H.L. (2006) Xylanase gene sequences from the genomic DNA of unpurified rumen microorganisms. Patent no. CA $2555063 \mathrm{C}$.

Collins T., Hoyoux A., Dutron A., Georis J., Genot B., Dauvrin T., Arnaut F., Gerday C., Feller G. (2005) Use of glycoside hydrolase family 8 xylanases in baking. J. Cereal. Sci. 43: 79-84.

Dauvrin T., Jonniaux J.L. (2004) Enzyme with xylanase activity. Patent no. Assignee: Puratos NV EP1130102B1.

Deshpande S.K., Bhotmange M.G., Chakrabarti T., Shastri P.N. (2008) Production of cellulase and xylanase by Trichoderma reesei (QM 9414 mutant), Aspergillus niger and mixed culture by solid state fermentation (SSF) of water hyacinth (Eichhornia crassipes). Ind. Jour. Chem. Technol. 15: 449-456.

Dumitriu S., Chornet E., Vidal P. (1997) Rock Forest Polyionic insoluble hydrogels comprising xanthan and chitosan. US Patent 5620706.

Eklund R., Zacchi G. (1995) Simultaneous saccharification and fermentation of steam-pretreated willow. Enzy. Microbiol. Technol. 17: 255-259.

Elgharbi F., Hlima H.B., Farhat-Khemakhem A., Ayadi-Zouari D., Bejar S., Hmida-Sayari A. (2015) Expression of US368 xylanase in: purification, characterization and copper activation. Inter. Jour. Biol. Macro. 74: 263-270.

Fadel M., Fouda M.S. (1993) Physiological studies on xylanase production by Penicillium fumiculosum on some agricultural wastes. Entralbl. Microbiol. 184: 304-312.

Fenel F., Turunen O., Leisola M. (1999) Method to improve the stability and broaden the $p H$ range of family $G / 11$ xylanases. Assignee: Danisco US Inc US 8846364 B2.

Fisher M., Petersson D. (2008) Xylanases for animal feed, Assigne: Novozymes, International Patent, WO/2008/ 037757.

Flores M.E., Perea M., Rodriguez O., Malvaez A., Huitron C. (1996) Physiological studies on induction and catabolite repression of xylosidase and endoxylanase in Streptomyces sp. CH-M-1035. J. Biotechnol. 49: 179-187.

Ganga A., Ampar Q., Salvador V., Daniel V., Andrew M., Franscisco P. (1998) Heterologous production in Saccharomyces cerevisiae of different Aspergillus nidulans xylanase of potential interest in oenology. J. Sci. Food Agric. 78: $315-320$.

Gasper A., Cosson T., Roques C., Thonart P. (1997) Study on the production of xylanolytic complex from Penicillium canescens 10-10c. Appl. Biochem. Biotechnol. 67: 45-67.

Gaur R., Lata S.K. (2005) Immobilization of xylan-degrading enzymes from Scytalidium thermophilum on Eudragit L-100. World J. Microbiol. Biotechnol. 21: 1123-1128.
Ge Y., Lili H., Fuliang Z. (2011) Study on the solid-state fermentation conditions for producing thermostable xylanase feed in a pressure pulsation bioreactor. Adv. Mater. Res. 236-238: 72-76.

Ghoshal G., Banerjee U.C., Shivhare U.S. (2015a) Isolation, screening and optimization of xylanase production in submerged fermentation using $P$. citrinum. J. Sci. Indus. Res. 74: 400-405.

Ghoshal G., Banerjee U.C., Shivhare U.S. (2015b) Utilization of agrowaste and xylanase production in solid state fermentation. J. Biochem. Tech. 6: 1013-1024.

Gomes D.J., Gomes J., Steiner W. (1994) Factors influencing the induction of endo-xylanase by Thermoascus aurantiacus. J. Biotechnol. 33: 87-94.

Gosalves M.J., Perez-Gonzalez J.A., Gonzalez R., Navarro A. (1991) Two $\beta$-glycanase genes are clustered in Bacillus polymyxa: Molecular cloning expression and sequence analysis of genes encoding a xylanase and an endo- $\beta-(1,3)$ (1,4)-glucanase. J. Bacteriol. 173: 7705-7710.

Goswami G.K., Pathak R.R. (2013) Microbial xylanases and their biomedical applications: a review. Int. J. Basic Clin. Pharmacol. 2: 237-246.

Gupta S., Bhushan B., Hoondal G.S. (2000) Isolation purification and characterization of xylanase from Staphylococcus Sp. SG-13 and its application in biobleaching of kraft pulp. J. Appl. Microbiol. 88: 325-334.

Gupta G., Sahai V., Gupta R.K. (2013) Optimization of xylanase production from Melanocarpus albomyces using wheat straw extract and its scale up in stirred tank bioreactor. Ind. J. Chem. Technol. 20: 282-289.

Haq I., Khan A., Butt W.A., Ali S., Qadeer M.A. (2002) Effect of carbon and nitrogen sources on xylanase production by mutant strain of Aspergillus niger GCBMX-45. J. Biol. Sci. 2: 143-144.

Hiremath K.S., Patil C.S. (2011) Isolation, production and characterization of alkalo thermostable xylanase from newly isolated Bacillus sp. Int. J. Biotechnol. Appl. 3: 48-51.

Holker U., Hofer M., Lenz J. (2004) Biotechnological advantages of laboratory-scale solid-state fermentation with fungi. Appl. Microbiol. Biotechnol. 64: 175-186.

Hu J., Arantes V., Saddler J.N. (2011) The enhancement of enzymatic hydrolysis of lignocellulosic substrates by the addition of accessory enzymes such as xylanase: is it an additive or synergistic effect. Biotechnol. Biofuels. 4: 36 .

Huang X., Lin J., Ye X., Wang G. (2015) Molecular characterization of a thermophilic and salt- and alkaline-tolerant xylanase from Planococcus sp. SL4, a strain isolated from the sediment of a soda lake. J. Microbiol. Biotechnol. 25: 662-671.

Irfan M., Syed Q., (2012) Partial purification and characterization of Xylanase from Trichoderma viride produced under $S S F$. Int. J. Appl. Res. Nat. Prod. 5: 7-11.

Ito K., Ogasawara H., Sugimoto T., Ishikawa T. (2000) Purification and properties of acid stable xylanases from Aspergillus kawachii. Biosci. Biotech. Biochem. 56: 547-550. 
Jain A., Morlok C.K., Henson J.M. (2013) Comparison of solidstate and submerged-state fermentation for the bioprocessing of switchgrass to ethanol and acetate by Clostridium phytofermentans. Appl.Microbiol.Biotechnol. 97:905-917.

Jiang Z., Li X., Yang S., Li L., Tan S. (2005) Improvement of the bread making quality of wheat flour by the hyperthermophilic xylanase $B$ from Thermotoga maritime. Food Res. Int. 38: 37-43.

Juturu V., Wu J.C., (2012) Microbial xylanases: Engineering, production and industrial applications. Biotechnol. Adv. 30: 1219-1227.

Jun H., Bing Y., Keying Z., Xuemei D., Daiwen C. (2009) $E_{X-}$ pression of a Trichoderma reesei $\beta$-xylanase gene in Escherichia coli and activity of the enzyme on fiber-bound substrates. Protein Expr. Purif. 67: 1-6.

Kadowaki M.K., Souza C.G.M., Simao R.C.G., Peralta R.M. (1997) Xylanase production by Aspergillus tamari. Appl. Biochem. Biotechnol. 66: 97-106.

Kamble R.D., Jadhav A.R. (2012) Isolation, purification and characterization of xylanase produced by a new species of Bacillus in SSF. Intern. J. Microbiol. 1: 1-8.

Kansoh A.L., Gammel A. (2001) Xylanolytic activities of Streptomyces sp. 1,taxonomy production, partial purification and utilization of agricultural wastes. Acta. Microbiol. Immunol. Hung. 48: 39-52.

Kantelinen A., Hortling B., Sundquist J. et al. (1993) Proposed mechanism of the enzymatic bleaching of kraft pulp with xylanases. Holzforschung - Intern. J. Biol. Chem. Phys. Technol. Wood 47(4): 318-324.

Kermnický L., Biely P. (1998) Disaccharides permeases: constituents of xylanolytic and mannanolytic systems of Aureobasidium pullulans. Biochim. Biophys. Acta. 1425:560-566.

Khasin A., Alchanati I., Shoham Y. (1993) Purification and characterization of a thermostable xylanase from Bacillus stearothermophilus T-6. Appl. Environ. Microbiol. 59: 1725-1730.

Kim S.W., Kang S.W., Lee J.S. (1997) Cellulase and xylanase production by Aspergillus niger KKS in various bioreactors. Biores. Technol. 59: 63-67.

Kimura T., Mizutani T., Tanaka T., Koyama T., Sakka K., Ohmiya K. (2003) Molecular breeding of transgenic rice expressing a xylanase domain of the gene from Clostridium thermocellum. Appl. Microbiol. Biotechnol. 62: 374-379.

Klingspohn U., Schügerl K. (1993) Integrated enzyme production in continuous operation by utilization of potato pulp. J. Biotechnol. 29: 109-119.

Kulkarni N., Shendye A., Rao M. (1999) Molecular and biotechnological aspects of xylanases. FEMS. Microbiol. Rev. 23: 411-456.

Kumar L., Nagar S., Mittal A., Garg N., Gupta V.K. (2014) Immobilization of xylanase purified from Bacillus pumilus VLK-1 and its application in enrichment of orange and grape juices. J. Food Sci. Technol. 51: 1737-1749.

Laurikainen T., Härkönen H., Autio K., Poutanen K. (1998) Effects of enzymes in fibre-enriched baking. J. Sci. Food Agric. 76: 239-249.
Lee W.C., Yusof S., Hamid S.A., Baharin B.S. (2006) Optimizing conditions for enzymatic clarification of banana juice using response surface methodology (RSM). J. Food Eng. 73: 55-63.

Lemos J.L.S., Peirera Junior N. (2002) Influence of some sugars on xylanase production by Aspergillus awamori in solid state fermentation. Brazilian Arch. Biol. Technol. 45(4): 431-437.

Liao H., Zheng H., Li S., Wei Z., Mei X., Ma H., Shen Q., Xu Y. (2015) Functional diversity and properties of multiple xylanases from Penicillium oxalicum GZ-2. Sci. Rep. 5: 12631.

Liu J.R., Yu B., Lin S.H., Cheng K.J., Chen Y.C. (2005) Direct cloning of a xylanase gene from the mixed genomic DNA of rumen fungi and its expression in intestinal Lactobacillus reuteri. FEMS Microbiol. Lett. 251: 233-241.

Liu C., Qiang Y., Qing Z., Shi-yuan Y. (1999) Study on the selective production of xylanase by Trichoderma reesei. Linchan Huaxue Yu Gongye 19: 8-12.

MacKenzie C.R., Yang R.C.A., Patel G.B., Bilous D., Narang S.A. (1989) Identification of three distinct xylanase genes of Clostridium thermocellum by molecular cloning. Arch. Microbiol. 152: 377-381.

Maldonado R.F., Vieira D.S., Alponti J.S., Bonneil E., Thibault P., Ward R.J. (2013) Engineering the pattern of protein glycosylation modulates the thermostability of a GH11 xylanase. J. Biol. Chem. 288: 25522-25534.

Malhotra G., Jeshreena R., Chapadgaonkar S.S. (2016) Aqueous two phase purification of xylanase obtained from a bacterial isolate. Int. J. Pharm. Bio. Sci. 7: 305-308.

Meng D.D., Ying Y., Chen X.H., Lu M., Ning K., Wang L.S., Li F.L. (2015) Distinct roles for carbohydrate-binding modules of glycoside hydrolase 10 (GH10) and GH11 xylanases from Caldicellulosiruptor sp. strain F32 in thermostability and catalytic efficiency. Appl. Environ. Microbiol. 81: 2006-2014.

Michelin M., Oliveira Motaa A.M., Lourdes M., Moraes Polizeli T., Silva D.P., Vicentea A.A., Teixeiraa J.A. (2013) Influence of volumetric oxygen transfer coefficient $(\mathrm{kLa})$ on xylanases batch production by Aspergillus niger van Tieghem in stirred tank and internal-loop airlift bioreactors. Biochem. Eng. J. 80: 19-26.

Miller G.L. (1959) Use of Dinitrosalicylic acid reagent for determination of reducing sugar. Ana. Chem. 31: 426-428.

Mitchell D.A., Berovic M., Krieger N. (2002) Overview of solid state bioprocessing. Biotechnol. Ann. Rev. 8: 183-225.

Motta F.L., Andrade C.C.P., Santana M.H.A. (2013) A review of xylanase production by the fermentation of xylan: Classification, characterization and applications. http://dx. doi.org/10.5772/53544.

Nevalainen K.M.H., Te’o V.S.J., Bergquist P.L. (2005) Heterologous protein expression in filamentous fungi. Trends Biotechnol. 23: 468-474.

Okazaki W., Akiba T., Horikoshi K., Akahoshi R. (1985) Purification and characterization of xylanases from alkalophilic thermophilic Bacillus sp. Agric. Biol. Chem. 49: 2033-2039. 
Pal A., Khanum F. (2011) Purification of xylanase from Aspergillus niger DFR-5: Individual and interactive effect of temperature and $\mathrm{pH}$ on its stability. Process Biochem. 46: 879-887.

Pandey A., Soccoll C.R., Mitchell D. (2000) New developments in solid-state fermentation: I - Bioprocesses and products. Process Biochem. 35: 1153-1169.

Panbangred W., Fukusaki E., Epifanio E.C., Shinmyo A., Okada H. (1985) Expression of a xylanase gene of Bacillus pumilus in Escherichia coli and Bacillus subtilis. Appl. Microbiol. Biotechnol. 22: 259-264.

Parajò J.C., Domínguez H., Domínguez J. (1998) Biotechnological production of xylitol. Part 1: Interest of xylitol and fundamentals of its biosynthesis. Biores Technol. 65: 191-201.

Paridah M.T., Basher A.B., Saiful Azry S., Ahmed Z. (2011) Retting process of some bast plant fibers and its effect on fiber quality: A review. BioResources 6(4): 5260-5281.

Patel R.N., Grabski A.C., Jefries T.W. (1994) Chromophore release from kraft by purified Srepmomices roseiscleroticus xylanase. Appl. Microbiol. Biotechnol. 39: 405-412.

Peij N.N.M.E., Gielkens M.M.C., de Vries R.P., Visser J., de Graff L.H. (1998) The transcriptional activator XInR regulates both xylanolytic and endoglucanase gene expression in Aspergillus niger. Appl. Environ. Microbiol. 64: 3615-3619.

Perez-Gonzalez J.A., De Graff L.H., Visser J., Ramon D. (1996) Molecular cloning and expression in Saccharomyces cerevisiae of two Aspergillus nidulans xylanase genes. Appl. Environ. Microbiol. 62: 2179-2182.

Pinaga F., Fernandez-Espinor M.T., Valles S., Roman D. (1994) Xylanase production in Aspergillus nidulans. Induction and carbon catabolite repression. Microbiol. Lett. 115: 319-324.

Polizeli M.L.T.M, Rizzatti A.C.S., Monti R., Terenzi H.F., Jorge J.A., Amorim D.S. (2005) Xylanases from fungi: properties and industrial applications. Appl. Microbiol. Biotechnol. 67: 577-591.

Poutanen K., Ratto M., Puls J., Viikari L. (1987) Evaluation of different microbial xylanolytic systems. J. Biotech. 6: 49-60.

Qiu J., Han H., Sun B., Chen Y., Yu C., Peng R., Yao Q. (2016) Residue mutations of xylanase in Aspergillus kawachii alter its optimum pH. Microbiol. Res. 182: 1-7.

Ratanakhanokchai K., Kyu K.L., Tanticharoen M. (1999) Purification and properties of a xylan-binding endoxylanase from alkaliphilic Bacillus sp. strain K-1. Appl. Env. Microbiol. 65: 694-697.

Rawashdeh R., Saadoun I., Mahasneh A. (2005) Effect of cultural conditions on Xylanase production by Streptomyces $s p$. (strain $1 b 24 D$ ) and its potential to utilize tomato pomace. African J. Biotechnol. 4: 251-255.

Rodríguez P., Oliveira N., Pérez F., Bibbins B., Belo I., Agrasar A.T., Domínguez J.M. (2014) Optimization of xylanase production by filamentous fungi in solid state fermentation and scale up to horizontal tube bioreactor. Appl. Biochem. Biotechnol. 173: 803-825.
Roy N., Habib R.M. (2009) Isolation and Characterization of Xylanase Producing strain of Bacillus cereus from soil. Iran. J. Microbiol. 2: 49-53.

Roy S., Dutta T., Ghosh. (2013) Novel xylanases from Simplicillium obclavatum MTCC 9604: comparative analysis of production, purification and characterization of enzyme from submerged and solid state fermentation. Springer plus. 2: 382-392.

Royer J.C., Nakas J.P. (1991) Purification and characterization of two xylanases from Trichodermalongibrachiatum. Euro. J. Biochem. 202: 521-529.

Rouau X. (1993) Investigations into the effects of an enzyme preparation for baking on wheat flour dough pentosans. J. Cereal. Sci. 18: 145-157.

Salles B.C., Medeiros R.G., Bao S.N., Silva Jr. F.G., Filho E.X.F. (2005) Effect of cellulase-free xylanases from Acrophia lophoranainiana and Humicola griseavarthermoidea on eucalyptus kraft pulp. Process Biochem. 40: 343-349.

Silva C.H.C, Puls J., Sousa M.V. de, Filho E.X.F (1999) Purification and characterization of a low molecular weight xylanase from solid-state cultures of Aspergillus fumigates fresnius. Revista de Microbiol. 30: 114-119.

Silva da C.A., Queiroz de A.E.S.F., Nascimento dos T.C.E.S., Rodrigues C., Gomes J.E.G., Souza-Motta C.M., Vandenberghe de L.P.S., Medeiros de E.V., Moreira K.A., Herculano P.N. (2014) Extractive fermentation of Xylanase from Aspergillus tamarii URM 4634 in a bioreactor. Appl. Biochem. Biotechnol. 173: 1652-1666.

Silva L.A.O, Fanchini Terrasanb C.R., Cano Carmona E. (2015) Purification and characterization of xylanases from Trichoderma inhamatum. Elect. J. Biotechnol. 18: 307-313.

Sriprang R., Asano K., Gobsuk J., Tanapongpipat S., Champreda V., Eurwilaichitr L. (2006) Improvement of thermostability of fungal xylanase by using site-directed mutagenesis. J. Biotechnol.126: 454-462

Sun Y., Cheng J. (2002) Hydrolysis of lignocellulosic materials for ethanol production: A review. Biores Technol. 83:1-11.

Subramaniyan S., Prema P. (2000) Cellulase-free xylanases from Bacillus and other microorganisms. FEMS Microbiol. Lett. 183: 1-7.

Takahashi Y., Kawabata H., Murakami S. (2013) Analysis of functional xylanases in xylan degradation by Aspergillus niger $E-1$ and characterization of the GH family 10 xylanase Xyn VII. Springer Plus 2: 447.

Taneja K., Gupta S., Kuhad R.C. (2002) Properties and application of a partially purified alkaline xylanase from an alkalophilic fungus Aspergillus nidulans KK-99. Biores. Technol. 85: 39-42.

Teixeira L.C., Linden J.C., Schroeder H.A. (2000) Simultaneous saccharification and co-fermentation of peracetic acid pretreated biomass. Appl. Biochem. Biotechnol. 84: 111-127.

Teplitsky A., Shulami S., Moryles S., Shoham Y., Shoham G. (2000) Crystallization and preliminary $X$-ray analysis of an intracellular xylanase from Bacillus stearothermophilus T-6. Acta. Crystallogr. D. Biol. Crystallogr. 56: 181-184. 
Thomas L., Joseph A., Arumugam M. Pandey A. (2013) Production, Purificaton, characterization and over-expression of Xylanases from Actinomycetes. Indian J. Exp. Biol. 51: 875-884.

Tundo P., He L.N., Lokteva E., Mota C. (2016) Chemistry Beyond Chlorine. Springer.

Twomey L.N., Pluske J.R., Rowe J.B., Choct M., Brown W., McConnell M.F., Pethick D.W. (2003) The effects of increasing levels of soluble non-starch polysaccharides and inclusion of feed enzymes in dog diets on faecal quality and digestibility. Anim. Feed Sci. Technol. 108: 71-82.

Umsza-Guez M.A., Díaz A.B., de Ory I., Blandino A., Gomes E., Caro I. (2011) Xylanase production by Aspergillus awamori under solid state fermentation conditions on tomato pomace. Braz. J. Microbiol. 42: 1585-1597.

Verma D., Satyanarayana T. (2013) Production of cellulasefree xylanase by the recombinant Bacillus subtilis and its applicability in paper pulp bleaching. Biotechnol. Prog. 29: 1441-1447.

Viikari L., Kantelinen A., Sundquist J., Linko M. (1994) Xylanases in bleaching: From an idea to the industry. FEMS Microbiol. Rev. 13(2-3): 335-350.

Walia A., Guleria S., Mehta P., Chauhan A., Parkash J. (2017) Microbial xylanases and their industrial application in pulp and paper biobleaching: a review. 3 Biotech. 7: $1-12$.

Wang C.H., Hangling Y., Haiwan H., Honghai G. (1998) Xylanase production and its application in degradation of hemicelluloses materials. Int. Cong. Biotechnol. Pulp Pap. Ind. 7: 65-67.

Walsh D.J., Gibbs M.D., Bergquist P.L. (1998) Expression and secretion of a xylanase from the extreme thermophile,
Thermotoga strain FjSS3B.1, in Kluyveromyces lactis. Extremophiles 2: 9-14.

Wase D.A.J., Raymahasay S., Wang W.C. (1985) Production of $\beta$-glucosidase, endo-1, 4-beta-D-glucanase and D-xylanase from straw by Aspergillus fumigates 255091. Enzyme Microbiol. Technol. 7: 225-229.

Wu K., Jingmin C., Jie Z., Bin L., Tu M., Tao W., Renrui P. (2000) Substrate specificities of xylanases from Aspergillus niger and its relationship of xylo-oligosaccharide production. Quanquo Gongye Weisheng wu Xinxi Zhongxin 30: 18-20.

Xiong L., Kameshwar A.K.S., Chen X., Guo Z., Mao C., Chen S., Qin W. (2016) The ACEII recombinant Trichoderma reesei QM9414 strains with enhanced xylanase production and its applications in production of xylitol from tree barks. Microbial Cell Factor. 15: 215-233.

Yinan Yang K.S., Ping L., Lul J. (2008) Cloning, sequencing and expression of a novel xylanase cDNA from a newly isolated Aspergillus awamori in Pichia pastoris. Afr. J. Biotechnol. 7: 4251-4259.

Zhou C., Yongtao W., Minchen W., Wu W., Li D. (2009) Heterologous expression of xylanase II from Aspergillus usamii in Pichia pastoris. Food Technol. Biotechnol. 1: 90-95.

Zafar A., Aftab M.N., Din Z.U., Aftab S., Iqbal I., Shahid A., Tahir A., Haq I.U. (2016) Cloning, expression, and purification of xylanase gene from Bacillus licheniformis for use in saccharification of plant biomass. Appl. Biochem. Biotechnol. 178: 294-311. 